\title{
Comparative Pollen Morphology of Allergic Salix Taxa Growing at Meşelik and Yunus Emre Campus in Eskişehir
}

\author{
Ismühan Potoğlu Erkara ${ }^{1}$, Okan Sezer*2 \\ ${ }^{1}$ Eskisehir Osmangazi University, Faculty of Science and Letters, Department of Biology, Eskisehir 26040, \\ Turkey, orcid.org/0000-0001-5780-4999 \\ ${ }^{2}$ Eskisehir Osmangazi University, Faculty of Science and Letters, Department of Biology, Eskisehir 26040, \\ Turkey, orcid.org/0000-0001-7304-1346 \\ *Corresponding author: ismuhan@ogu.edu.tr
}

Received: 24 November 2021, Accept: 26 November 2021, Published Online: 01 December 2021

\begin{abstract}
In this study, comparative palynological characteristics and allergic features of the Salix taxa from Meşelik and Yunus Emre campuses, Eskişehir/Turkey were investigated. Detailed palynomorphological investigation of the pollen grains of Salix taxa were carried out under Light Microscope and Scanning Electron Microscope (SEM). It was revealed that the pollen grains of investigated taxa were the tricolpatae type and spheroidal shaped. Exine was seen to be tectatae-reticulatae ornamentation. Comparisons which will be made with the collected species and other taxa within the family will make contribution to taxonomy for family.
\end{abstract}

Key words: Salix, Salicaceae, Pollen, Eskişehir

\section{Introduction}

Palynology is a branch of Botany in which all biological properties of pollen and spores are studied. This term was first introduced in 1945 by H.A Hyde and D.A Williams. The term palynology originates from the Latin word "Paluno", which means to sprinkle, distribute.

Morphological characteristics of pollen are important in taxonomic studies. In many cases, pollen morphologies are among the criteria used in the classification of families, genera or species. In groups that are phylogenetically close to each other, there are similarities in pollen morphologies as in other features.

Palinology has important contributions in the phylogenetic relationships of plants. Although palynology is a new science for Turkey, palynological studies has been increasing in recent years (Aytuğ, 1974; İnceoğlu et al., 1994; Pehlivan, 1995).

The contribution of palinology to plant taxonomy is extremely important. Plant systematists have to consider their morphological, anatomical and ecological features as well as their palynological features in 
determining and classifying plants. A classification based solely on morphological characters can lead to some inaccuracies. It is a fact that some morphological characters can change a lot depending on the external environmental conditions. With studies based on the morphological characteristics of pollens, today the classification of many plant families has been made more accurately and the origins of these families have been better understood.

Pollen morphology has an important contribution to modern systematic and phylogenetic researches on the discrimination of systematic groups. The classification system accepted by many plant systematists today has greatly benefited from pollen morphology and cytology.

The classification of pollens, which are essential in taxonomic studies, is made according to their shape, structure, and exine ornamentation. In this respect, ornamentation of the exine membrane, which forms the outer part of the pollen, are particularly important taxonomic character.

In recent years, obtained data from modern taxonomic studies are widely used in systematic investigations to reveal phylogenetic relationships. As a result of these studies, it was determined that the pollens are useful tools as different parts of plants for reveal evolutionary process in investigated taxa. So, studies that reveal the palynological characteristics of plants are carried out in many countries. The data obtained from these studies are compared with the types of fossil pollens in the past geological periods and the links between the evolutionary process of plant taxa are revealed.

In addition to all these researches, in recent years, palynological studies conducted with electron microscopy have made the precise distinction of plant species in taxonomic terms and phylogenetic relationships have been revealed. By using electron microscopy, the structure of the exine and intine layers of the pollen was examined in detail, and thus it was possible to distinguish at the level of variety, race, or even population.

Investigating the differences in the sizes of pollen grains and surface ornamentation are used as a very useful method in terms of distinguishing different varieties and types. Even the pollens and different clones of each species can be distinguished by the exine membrane surface structure.

Palynological studies; It helps to reveal new plant taxa in taxonomic terms. The morphological properties of pollen can be determined by light and electron microscopy. Based on the similarities and differences of these morphological features between taxa, plant identification keys based on robust and invariant characters can be prepared. Palynological studies also help to easily identify and classify various plant taxa in the regions where they are carried out. Moreover, these studies help to distinguish between natural and cultivated plant hybrids. Palynological studies provide important clues about the evolution of plants. With the help of electron microscopy, it enables the determination of the exact taxonomic characteristics of plants at the level of genus, species, even clones, and to investigate their phylogenetic relationships.

In this study conducted in Eskişehir Meşelik and Yunus Emre Campuses, the pollens of allergic Salix taxa and varieties were determined and their morphological characteristics were determined. With the data obtained within the scope of this study, it is aimed to shed light on plant systematics and to assist doctors in the diagnosis and treatment of allergic diseases. 


\section{Material and Methods}

The study material consists of pollens of Salix taxa grown in Eskişehir Meşelik and Yunus Emre Campuses between 2020-2021. The plant sampling process was carried out during the spring months in the 2020-2021 period. Pollen samples collected from newly opened flowers for palynological studies were labeled and stored in paper envelopes.

In palynological studies, pollens obtained from flowers of 10-15 different plants for each Salix taxa were used. During the collection of plants, samples belonging to the studied taxa were placed separately in paper envelopes to prevent the mixing of different pollens. In our study, the pollen morphology of taxa were examined by Scanning electron microscopy and light microscopy. The terminology of Faegri and Iversen has been used in naming the exine layers.

The examination of current pollens under the light microscope was done by Wodehouse (1935) and fossilized pollens by Erdtman (1969) methods. Morphological examination of the pollens was done under Nikon binocular microscope by oil immersion lens $(x 100)$. All parameters were measured 50 times to determine the averaged values. Standard deviation and variations have been calculated. Each range in the ocular micrometer is $0.98 \mu \mathrm{m}$. Microphotographs were taken with a Nikon 80i type microscope and a KAMERAM Digital camera in the Eskişehir Osmangazi University, Faculty of Arts and Science, Department of Biology. The magnification of the photos is $x$ 1000. For Scanning electron microscopy (SEM) examinations, unacetholyzed pollen grains were placed on the fixing plate and covered with gold and examined under Jeol 5600 LV Scanning electron microscope (SEM) (Walker, 1974a-b).

Various basic palynological books and various studies have been used for the diagnosis of pollen (Wodehouse, 1935; Kuprianova, 1967; Erdtman, 1969; Aytuğ et al., 1971; Charpin et al., 1974; Faegri and Iversen, 1975; Walker, 1974a-b; Moore et al., 1991).

\section{Results}

Salicaceae is a family of deciduous trees and shrubs that have monogamous catkins on different plants. Each catkin has a central axis which bears many small flowers. Each of the flowers on the catkin is laterally positioned and has a paper-like bract. Male flowers have two or more stamen. In cintrast to male ones, female flowers have a single pistile. Its fruit is dry. The ripening fruit is divided into 2-4 pieces and emits a large number of white hairy cottony seeds. Salicaceae taxa grow in sunny places and temperate climates. Also they prefers loose, deep, sandy-clay soils. They are produced with seeds and cuttings. Motherland is the region from Turkey to Central Asia and Japan.

Species: Salix babylonica (Salkım söğüt)

Turkish name: Salkım söğüt

Polen Type: Tricolpatae

Pollen Shape: Spheroidal P/E $=1,15 \mu \mathrm{m}(\mathrm{W}) ; 1,07 \mu \mathrm{m}(\mathrm{E})$

Exine: Average thickness $0,82 \mu \mathrm{m}(\mathrm{W}) ; 0,84 \mu \mathrm{m}(\mathrm{E})$ 
Aperture: Colpi are wide and long with clear boundaries, pointed tips.

Structure: Tectatae

Sculpture: Reticulatae

Table 1. Morfometric Data of Salix babylonica.

\begin{tabular}{|c|r|r|r|r|r|}
\hline \multicolumn{3}{|c|}{ Wodehouse Method } & \multicolumn{3}{c|}{ Erdtman Method } \\
\hline & \multicolumn{1}{|c|}{$\mathrm{M}$} & $\mathrm{S}$ & \multicolumn{1}{c|}{$\mathrm{M}$} & \multicolumn{2}{|c|}{$\mathrm{S}$} \\
\hline $\mathbf{P}$ & 19,16 & $\pm 1,43$ & 18,82 & $\pm 1,04$ & $\mu \mathrm{m}$ \\
\hline $\mathbf{E}$ & 16,22 & $\pm 0,61$ & 17,14 & $\pm 1,89$ & $\mu \mathrm{m}$ \\
\hline $\mathbf{c l g}$ & 16,58 & $\pm 1,93$ & 14,36 & $\pm 3,20$ & $\mu \mathrm{m}$ \\
\hline $\mathbf{c l t}$ & 6,25 & $\pm 1,02$ & 6,84 & $\pm 1,44$ & $\mu \mathrm{m}$ \\
\hline $\mathbf{L}$ & 16,57 & $\pm 1,14$ & 19,56 & $\pm 1,41$ & $\mu \mathrm{m}$ \\
\hline $\mathbf{t}$ & 8,34 & \pm 1.22 & 8,00 & $\pm 1,00$ & $\mu \mathrm{m}$ \\
\hline $\mathbf{i}$ & 0,50 & $\pm 0,00$ & - & - & $\mu \mathrm{m}$ \\
\hline Ex & 0,82 & $\pm 0,26$ & 0,84 & $\pm 0,24$ & $\mu \mathrm{m}$ \\
\hline
\end{tabular}

Species: Salix babylonica cv. varigata

Turkish name: Alacalı söğüt

Pollen Type: Tricolpatae

Pollen Shape: Spheroidal $P / E=1,08 \mu \mathrm{m}(\mathrm{W}) ; 1,14 \mu \mathrm{m}(\mathrm{E})$

Exine: Average thickness $1 \mu \mathrm{m}(\mathrm{W}) ; 0,82 \mu \mathrm{m}(\mathrm{E})$

Aperture: Colpi are wide and long with clear boundaries, pointed tips.

Structure: Tectatae

Sculpture: Reticulatae

Table 2. Morfometric Data of Salix babylonica cv. varigata.

\begin{tabular}{|c|c|c|c|c|c|}
\hline \multicolumn{3}{|c|}{ Wodehouse Method } & \multicolumn{3}{c|}{ Erdtman Method } \\
\hline & $\mathrm{M}$ & $\mathrm{S}$ & $\mathrm{M}$ & \multicolumn{2}{c|}{$\mathrm{S}$} \\
\hline $\mathbf{P}$ & 20,12 & $\pm 2,44$ & 21,61 & $\pm 3,18$ & $\mu \mathrm{m}$ \\
\hline $\mathbf{E}$ & 18,46 & $\pm 2,10$ & 19,58 & $\pm 2,86$ & $\mu \mathrm{m}$ \\
\hline $\mathbf{c l g}$ & 16,20 & $\pm 2,30$ & 19,00 & $\pm 3,23$ & $\mu \mathrm{m}$ \\
\hline clt & 5,90 & $\pm 1,52$ & 7,60 & $\pm 1,07$ & $\mu \mathrm{m}$ \\
\hline $\mathbf{L}$ & 18,40 & $\pm 1,17$ & 22,30 & $\pm 3,59$ & $\mu \mathrm{m}$ \\
\hline $\mathbf{t}$ & 8,11 & $\pm 1,21$ & 9,00 & $\pm 1,33$ & $\mu \mathrm{m}$ \\
\hline $\mathbf{i}$ & 0,70 & $\pm 0,26$ & - & - & $\mu \mathrm{m}$ \\
\hline Ex & 1,00 & $\pm 0,00$ & 0,82 & $\pm 0,24$ & $\mu \mathrm{m}$ \\
\hline
\end{tabular}

Species: Salix caprea

Turkish name: Keçi söğüdü

Pollen Type: Tricolpatae 
Pollen Shape: Sphaeroidea P/E $=0,89 \mu \mathrm{m}(\mathrm{W}) ; 1,03 \mu \mathrm{m}(\mathrm{E})$

Exine: Average thickness $1 \mu \mathrm{m}(\mathrm{W}) ; 1,09 \mu \mathrm{m}(\mathrm{E})$

Aperture: Colpi are thin and long with clear boundaries, pointed tips.

Structure: Tectatae

Sculpture: Reticulate

Table 3. Morfometric Data of Salix caprea.

\begin{tabular}{|c|c|c|c|c|c|}
\hline \multicolumn{3}{|c|}{ Wodehouse Method } & \multicolumn{3}{c|}{ Erdtman Method } \\
\hline & $\mathrm{M}$ & $\mathrm{S}$ & $\mathrm{M}$ & \multicolumn{2}{c|}{$\mathrm{S}$} \\
\hline $\mathbf{P}$ & 21,48 & $\pm 1,51$ & 19,16 & $\pm 1,67$ & $\mu \mathrm{m}$ \\
\hline $\mathbf{E}$ & 24,19 & $\pm 2,21$ & 17,78 & $\pm 1,36$ & $\mu \mathrm{m}$ \\
\hline clg & 18,16 & $\pm 1,63$ & 15,88 & $\pm 1,44$ & $\mu \mathrm{m}$ \\
\hline clt & 10,12 & $\pm 2,14$ & 7,84 & $\pm 1,98$ & $\mu \mathrm{m}$ \\
\hline $\mathbf{L}$ & 23,52 & $\pm 1,64$ & 19,57 & $\pm 0,94$ & $\mu \mathrm{m}$ \\
\hline $\mathbf{t}$ & 8,15 & $\pm 1,22$ & 9,27 & $\pm 1,16$ & $\mu \mathrm{m}$ \\
\hline $\mathbf{i}$ & 0,70 & $\pm 0,26$ & - & - & $\mu \mathrm{m}$ \\
\hline Ex & 1,00 & $\pm 0,00$ & 1,09 & $\pm 0,18$ & $\mu \mathrm{m}$ \\
\hline
\end{tabular}

Species: Salix caprea cv. pendula

Turkish name: Sarkık keçi söğüdü

Pollen Type: Tricolpatae

Pollen Shape: Sphaeroidea P/E = 0,94 $\mu \mathrm{m}(\mathrm{W}) ; 0,89 \mu \mathrm{m}(\mathrm{E})$

Exine: Average thickness $1 \mu \mathrm{m}(\mathrm{W}) ; 0,89 \mu \mathrm{m}(\mathrm{E})$

Aperture: Colpi are thin and long with clear boundaries, pointed tips.

Structure: Tectatae

Sculpture: Reticulate-Perforate

Table 4. Morfometric Data of Salix caprea cv. pendula.

\begin{tabular}{|c|c|c|c|c|c|}
\hline \multicolumn{3}{|c|}{ Wodehouse Method } & \multicolumn{3}{c|}{ Erdtman Method } \\
\hline & $\mathrm{M}$ & $\mathrm{S}$ & $\mathrm{M}$ & \multicolumn{2}{c|}{$\mathrm{S}$} \\
\hline $\mathbf{P}$ & 21,47 & $\pm 1,56$ & 16,31 & $\pm 1,01$ & $\mu \mathrm{m}$ \\
\hline E & 23,42 & $\pm 1,52$ & 17,16 & $\pm 1,14$ & $\mu \mathrm{m}$ \\
\hline clg & 16,78 & $\pm 2,89$ & 12,25 & $\pm 1,41$ & $\mu \mathrm{m}$ \\
\hline clt & 7,77 & $\pm 2,14$ & 5,85 & $\pm 0,66$ & $\mu \mathrm{m}$ \\
\hline L & 22,40 & $\pm 1,51$ & 17,33 & $\pm 1,87$ & $\mu \mathrm{m}$ \\
\hline $\mathbf{t}$ & 9,28 & $\pm 1,32$ & 7,36 & $\pm 0,71$ & $\mu \mathrm{m}$ \\
\hline $\mathbf{i}$ & 0,70 & $\pm 0,26$ & - & - & $\mu \mathrm{m}$ \\
\hline Ex & 1,00 & $\pm 0,00$ & 0,89 & $\pm 0,33$ & $\mu \mathrm{m}$ \\
\hline
\end{tabular}




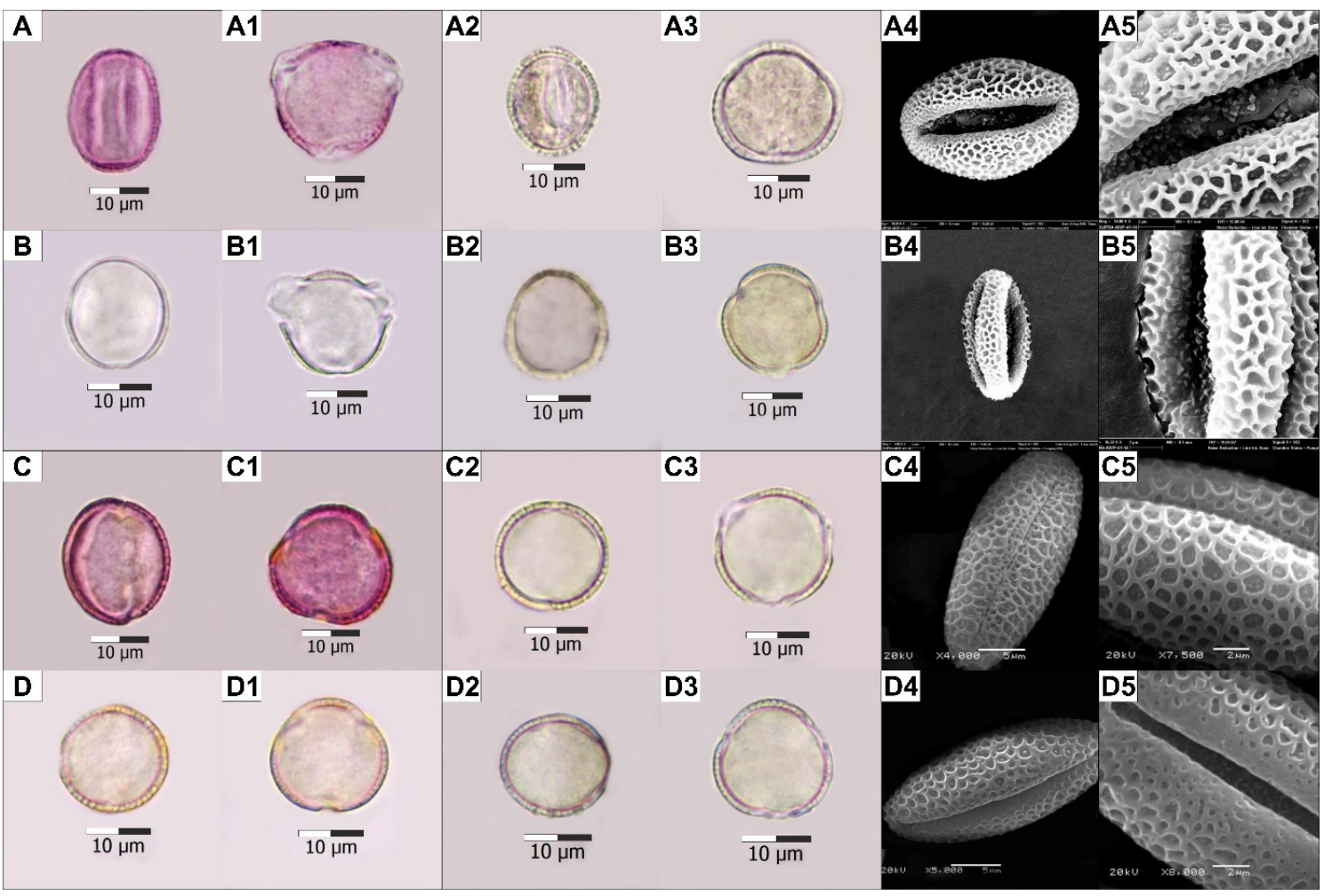

Figure 1. LM (A-D: Equatorial (W), A1-D1: Polar (W), A2-D2: Equatorial (E), A3-D3: Polar (E)) and SEM (A4-D4: Equatorial view, A5-D5: Exine ornamentation) microphotographs of investigated taxa (A-A5: Salix babylonica, BB5: Salix babylonica cv. varigata, C-C5: Salix caprea, D-D5: Salix caprea cv. pendula).

\section{Discussion}

In this study, pollen morphology of allergic Salix taxa and cultivars grown in Eskişehir Meşelik and Yunus Emre Campuses were studied at the level of light microscopy and SEM. Additionally, the pollination season of Salix taxa and its cultivars and their presence in parks and gardens were also revealed.

It has been determined that the pollen of Salix taxa is higher than other tree pollens in the air with a rate of $9.16 \%$ during the months of May-June in 2020-2021 in the research region, and reached the highest density in May (Potoğlu Erkara, 2009). This result shows that Salix taxa are widely distributed plants in Eskişehir Province and its surroundings. The data obtained are also compatible with the Salix pollen rates determined in the atmosphere of Ankara, Bursa, Bozüyük and Zonguldak provinces (Innceoğlu et al., 1994; Bıçakçı et al., 1996; Kaplan, 2004; Potoğlu Erkara, 2009).

The differences between the results of the studies conducted in Eskişehir and other provinces are due to regional, seasonal and climatic characteristics and differences in flora and vegetation. Eskişehir climatic data shows that there is an increase in temperature from January to August. These data are also compatible with the temperature data obtained from the measurements carried out within the scope of the study. A coordination was also observed between the increase in temperature between January and May and the amount of pollen. There is a positive correlation between the increasing temperature and the amount of pollen in the atmosphere of the 
research region between January and May, and this is in accordance with the pollen analysis studies conducted in the atmospheres of Brazil, Istanbul, America, Ankara, Sivas, Bozüyük and Zonguldak and Eskişehir, respectively (Mendes, 1949; Aytuğ, 1974; Mc. Donald, 1980; İnceoğlu et al., 1994; Pehlivan and Özler, 1995; Şalkurt, 2003; Kaplan, 2004; Potoğlu Erkara, 2009). Relative humidity, precipitation and wind speed are as important factors as temperature on the amount of pollen in the atmosphere. The fact that the wind speed and direction were not variable during the study and this provided the most suitable environment for pollen distribution. Many flowering plants have highest pollination in May. Because the May is the most intense month of flowering of plants. The reason for this change is related to meteorological factors, and it has been determined that pollination increases with the increase in air temperature and wind, and high temperature and relative humidity have a positive effect on the proliferation of pollen in the air. This finding is also compatible with Aytuğ's (1971-1973) aeropalynological research in the atmosphere of İstanbul. The reason for the increase in pollination due to the increase in air temperature is attributed to the opening of pollen sacs. It was determined that flowering was slow and short in the dry seasons, and an increase in the number of pollen was observed when the rainy days were many. This finding is also compatible with the literature Kessler (1953) and Mendes (1949).

The increase in temperature and the decrease in relative humidity after precipitation increase the amount of pollen in the atmosphere (İnceoğlu et al., 1994; Mc. Donald, 1980). While the temperature in Eskişehir's atmosphere increases until August, the amount of pollen begins to decrease from the first week of June. The reason for this decrease is due to the end of the pollination period of woody plants, which are anemogamous and give a large amount of pollen to the air, rather than meteorological factors.

In sunny and rainy weather, with the increase in temperature, humidity also increases and positively affects the increase in the number of pollen (Hyde and Williams, 1945; Hobday, 1973). Pollen decreased on rainy days because pollination was prevented. After the rain in Eskişehir, the increase in temperature and humidity and the increase in pollen were also observed. In addition, it is thought that the pollen concentration in the air is reduced to zero as a result of a strong rainfall washing the air (Aytuğ, 1974).

Pollens of Salix taxa grown in Eskişehir Meşelik and Yunus Emre Campuses are highly allergenic. It has been reported that it is among the most important allergen pollen causing hay fever (Havnen, 1974). Also it has been revealed that Salix pollens are among the pollens with the highest allergic effect in some countries such as Czechoslovakia (Rybníček et al., 1991). For this reason, we believe that pollen of Salix taxa and varieties grown in Eskişehir Meşelik and Yunus Emre Campuses is important in terms of allergic diseases.

It has been reported that the majority of pollens cause hay fever and pollen pollution is the dominant factor in hay fever in cities (Keynan et al., 1991). In addition, it has been shown that pollen and fungal spores in the air cause very high allergenicity due to their concentrations and allergy tests are useful in the manifestation of symptoms (Cosentino et al., 1995).

In Serik (Antalya), it was stated that people sensitive to pollen should take the necessary precautions outside at certain times in the relationship between pollens and meteorological factors (Ince and Pehlivan, 1988). Similar studies have been carried out in Russia and some other countries, revealing the pollination periods of the pollen and ensuring that the people of the sensitive region act cautiously (Savitsky and Kobzar, 1996). It has 
been shown that it helps in the diagnosis and treatment of seasonal rhinoconjunctivitis and pollen-induced asthma (Bass and Morgan, 1997).

People are more affected by pollen with high allergenic effect, especially during the pollination period. The more sensitive people stay away from allergen pollens during the pollination period, the less they will be affected by the allergic effects of these pollens.

In this study; Pollen morphology of allergic Salix taxa and varieties grown in Eskişehir Meşelik and Yunus Emre Campuses were determined. In addition, considering the effects of pollen on human health, we believe that the data presented in this study will shed light on doctors and people who are sensitive to pollen living in and around Eskişehir.

\section{Conflicts of Interests}

Authors declare that there is no conflict of interests

\section{References}

Aytug, B., Aykut, S., Merev, N., \& Edis, G. (1971). Pollen atlas of plants from environs of Istanbul. Yayın, 1654, 174.

Aytug, B. (1974). Pollen Calendar for İstanbul, Turkey. In: J. Charpin \& R. Surinyach (Eds.), Atlas of European Allergenic Pollens (pp. 205-216). Paris: Sandoz Editions.

Bass, D., \& Morgan, G. (1997). A three year (1993-1995) calendar of pollen and Alternaria mould in the atmosphere of south western Sydney. Grana, 36(5), 293-300.

Bıçakçı, A., Akkaya, A., Malyer, H., Ünlü, M., \& Sapan, N. (1996). Isparta ilinin atmosferik polenleri. SDÜ Tıp Fakültesi Dergisi, 3(4), 37-51.

Charpin, J., Surinyach, R. O., \& Frankland, A. W. (1974). Atlas Européen Des Pollens Allergisants: Atlas of European Allergenic Pollens, Sandoz.

Cosentino, S., Fadda, M. E., \& Palmas, F. (1995). Pollen and mould allergy in Southern Sardinia (Italy): comparison of skin-test frequencies and air sampling data. Grana, 34(5), 338-344.

Erdtman, G. (1969). Handbook of Palynology, Morphology, Taxonomy, Ecology. An Introduction to the Study of Pollen Grains And Spores. New York: Hafner Publ.

Erkara, I. P., Cingi, C., Ayranci, U., Gurbuz, K. M., Pehlivan, S., \& Tokur, S. (2009). Skin prick test reactivity in allergic rhinitis patients to airborne pollens. Environmental Monitoring and Assessment, 151(1), 401412.

Faegri, K. \& Iversen, J. (1975). Textbook of Pollen Analysis. 295 pp. Munksgaard, Copenhagen.

Havnen, J. (1974). Prick test and intracutaneous test-variability in histamine tests between different individuals and in same individual. In Acta Allergologica, 29(3), 225-227.

Hyde, H. A., \& Williams, D. A. (1945). Pollen analysis circular. Nature, 155, 265. 
Hobday, J. D., \& Stewar, A. J. (1973). The relationship between daily asthma attendance, weather parameters, spore count and pollen count. Australian and New Zealand Journal of Medicine, 3(6), 552556.

İnce, A., \& Pehlivan, S. (1988). Antalya ili Serik ilçesi havasındaki polenlerin meteorolojik faktörlerle ilişkisinin araştıııması. G. Ü. Gazi Eğitim Fakültesi Dergisi, 4, 287-298.

İnceoğlu, Ö., Pinar, N. M., Şakiyan, N. \& Sorkun, K. (1994). Airborne pollen concentration in Ankara, Turkey 1990-1993. Grana, 33(3), 158-161.

Kaplan, A. (2004). Airborne pollen grains in Zonguldak, Turkey, 2001-2002. Journal of Integrative Plant Biology, 46(6), 668.

Keynan, N., Waisel, Y., Shomer-llan, A., Goren, A., \& Brener, S. (1991). Annual variations of air-borne pollen in the coastal plain of Israel. Grana, 30(2), 477-480.

Kuprianova, L. A. (1967). Apertures of pollen grains and their evolution in Angiosperms. Review of Palaeobotany and Palynology, 3(1-4), 73-80.

McDonald, M. S. (1980). Correlation of air-borne grass pollen levels with meteorological data. Grana, 19(1), 53-56.

Mendes, E. (1949). Pollen allergy in the city of São Paulo, Brazil. Annals of Allergy, 7(6), 787.

Moore, P. D., Webb, J. A. \& Collinson, M. E. (1991). Pollen Analysis, 2nd ed., Chapter 6: 110-112.

Pehlivan, S. (1995). Türkiye'nin Alerjen Polenleri Atlası. Ankara: Ünal Ofset Matbaacılık Sanayi ve Ticaret Ltd. Şirketi, 191.

Pehlivan, S., \& Özler, H. (1995). Sivas ili atmosferindeki polenlerin araştıılması. Gazi University Journal of Science and Technology, 7, 69-77.

Rybníček, O., Rybníček, K., \& Počta, L. (1991). Pollen allergies in czechoslovakia: Pollen incidence and immunotherapy. Grana, 30(1), 150-154.

Savitsky, V. D., \& Kobzar, V. N. (1996). Aerobiology in Russia and Neighbouring Countries, 1980-1993: A Bibliographic Review. Grana, 35(5), 314-318.

Walker, J. W. (1974a). Aperture evolution in the pollen of primitive angiosperms. American Journal of Botany, 61(10), 1112-1137.

Walker, J. W. (1974b). Evolution of exine structure in the pollen of primitive angiosperms. American Journal of Botany, 61(8), 891-902.

Wodehouse, P. P. (1935). Pollen Grains. Mc Graw-Hill, New York. 